\title{
Lessons from Community Based Participatory Integrated Watershed Management, the Case of Somodo Watershed, South-Western Ethiopia, A Review
}

\author{
Leta Hailu $^{1 *}$, Wondimagegn Teka ${ }^{1}$ and Gizaw Tesfaye ${ }^{2}$ \\ ${ }^{1}$ Ethiopian Institute of Agricultural Research, Jimma Agricultural Research Center, Ethiopia \\ ${ }^{2}$ Ethiopian Institute of Agricultural Research, Melkasa Agricultural Research Center, Ethiopia
}

Submission: January 14, 2021; Published: February 02, 2021

*Corresponding author: Leta Hailu, Ethiopian Institute of Agricultural Research, Jimma Agricultural Research Center, Jimma, Ethiopia

\begin{abstract}
Land degradation due to soil erosion is a serious problem for the agricultural sector of developing countries. Somodo watershed is degraded due to inappropriate land use, overgrazing, and high rainfall causing severe soil erosion. A community based participatory integrated watershed management program has been proposed and implemented at Somodo watershed since 2011 to solve biophysical and socioeconomic related problems. Therefore, the objective of the study is to summarize the major interventions and achievements of the watershed. Before the intervention of different technologies, problems were identified and prioritized by the community of the watershed. Awareness creation and capacity building training were held in the watershed for more than 264 farmers, 47 DAs, and 49 administration staffs on different technologies at different times. Soil erosion control measures, soil fertility enhancement practices, niche compatible multipurpose trees introduction, and other interventions were implemented. River discharge and suspended sediment were monitored at the outlet of the watershed. Accordingly, more than $190 \mathrm{~km}$ soil bund and $45 \mathrm{~km}$ Vetiver hedgerows were done in the watershed, and 25,455 multipurpose tree seedlings and 40,000 seedlings of five improved coffee varieties have been raised at community nursery and planted in the watershed. Improved varieties of various fruits and crops were introduced and well adapted in the watershed. Demonstration of lime technologies was introduced on 35 ha of 140 farmer's farmlands. The established level soil bund stabilized with vetiver hedgerows were significantly $(\mathrm{P}<0.01)$ affected SMC $(\%), \mathrm{BD}(\mathrm{g} /$ $\mathrm{cm}^{3}$ ), and SOC (\%) on conserved croplands. Two years aged vetiver hedgerows reduced slope of treated farmland by 2.5 (\%) and improved available phosphorus and exchangeable acidity above the hedgerows. The soil pH has slightly increased in limed and enhanced yield of crops. In general, the study revealed that the intervention of integrated watershed management (IWM) increases household source of income, improved the practice of soil and water conservation (SWC), utilization of organic and inorganic fertilizers that enhances the soil quality and reduce the risk of soil erosion. Furthermore, socioeconomic related factors of the farmers were improved as compared to the base year. In summary, as a result of the IWM interventions, the discharge of the water had shown an increasing trend while sediment yield showed a decreasing trend from the base year. Therefore, IWM is a suggested approach to improve natural resource management and to sustain the livelihood of the community.

Keywords: Soil erosion; IWM; Interventions; Somodo watershed
\end{abstract}

\section{Introduction}

In Ethiopia, soil erosion is one of a serious problem challenging the agricultural sector and economic development [1]. It is severe in general and particularly in the highland areas where land highly degraded and exacerbates the prevailing of food insecurity in the country [2]. For several decades, integrated and sustainable watershed management has been suggested and tried in several countries in the world, as an effective way to address complex water and land resource challenges. Integrated watershed management (IWM) is being promoted as a suitable strategy for improving productivity and sustainable intensification of agriculture in rain fed drought prone regions of the world. Watershed management (WM) encompasses the holistic approach to manage watershed resources that integrates forestry, agriculture, pasture and water management, which can be broadened to rural development with a strong link to the livelihoods of the local people [3]. Integrated watershed management (IWM) interventions and improved access to markets and agricultural innovations are useful strategies for reducing poverty, improving livelihood resilience and sustainability in less-favored areas. Some benefits of IWM are non-tangible public goods, and hence not fully captured by individual resource users [4]. 
The Somodo Watershed of southwestern Ethiopia is well known for its inappropriate land use, high population pressure, overgrazing, and high rainfall, which are causing severe soil erosion for the past many years [5-7]. The watershed mean annual soil loss rate was found 18.69-ton ha $^{-1}$ year-1 ranging from negligible value to 131.21 -ton ha $^{-1}$ year $^{-1}$ identified using GIS based USLE model [6]. Most of the sub watershed has soil loss more than 20 -ton ha $^{-1}$ year-1, which is not in the acceptable range of annual soil loss of 11-ton ha- ${ }^{-1}$ year $^{-1}$. Soil erosion by water is a major watershed problem of agricultural production of the country that causes significant loss of soil fertility, loss of productivity and environmental degradation and final results to yield reduction and suffers the surrounding community to food insufficiency $[8,9]$.

In general, fourteen (14) problems were identified and prioritized by the community in the watershed, which requires appropriate interventions for the identified problems. Accordingly, to alleviate the land degradation induced due to soil erosion and socioeconomic problem of the watershed. Jimma Agricultural Research center under the Ethiopian Institute of Agricultural Research have extensively implemented integrated watershed management for the past nine years in the Somodo Watershed. Therefore, the objective of this review is to summarize the major interventions and achievements of Somodo model watershed management in its existing periods.

\section{Overview of the Somodo Watershed}

Somodo model watershed was selected by the Ethiopian Institute of Agricultural Research of Jimma Agricultural Research Center (EIAR-JARC) in 2011 as a demonstration and Coffee based learning model watershed for sustainable natural resource management. The watershed is located in the upper part of the Dhidhessa catchment in the Nile basin, in the Jimma zone of Oromia regional state, Southwestern part of Ethiopia. It lies between $7^{\circ} 46^{\prime} 00^{\prime \prime}-7^{\circ} 47^{\prime} 00^{\prime \prime} \mathrm{N}$ latitude and $36^{\circ} 48^{\prime} 00^{\prime \prime}-36^{\circ} 47^{\prime} 00^{\prime \prime} \mathrm{E}$ longitude with altitude ranging from $1900-2050 \mathrm{~m}$ a.s.l. (Figure 1). It covers 400 hectares and comprises about 300 households. On average it receives $1800 \mathrm{~mm}$ annual rainfall. Nitisol is a dominant soil type and about $68 \%$ of the watershed soil is extremely acidic ( $\mathrm{pH}$ value 3.75 to 4.5 ). The watershed is characterized by different land use types by cultivation land domination and less forested area. Coffee based and agro-forestry systems are common farming systems in the watershed. The average land holding size of household is 1.08 ha and half of the house hold owns less than 0.75 ha of land $[5,6]$.

Major Interventions and Achievements in the Watershed

\section{Awareness creation and capacity building}

Prior to dissemination of new technology to the area and conducting demonstration, all stakeholders are participated on awareness creation of the community with different training, then the local farmers capacitated on modern agricultural technologies and know the ways of watershed management interventions. Based on this, about 264 farmer households out of 290 (91\%) has been trained, and 47 and 49 development agents and administration facilitators have been trained, respectively. Totally, 360 participants involved in the watershed management capacity building program (Table 1 ).

Table 1: Training and demonstration given for capacity building.

\begin{tabular}{|c|c|c|c|c|c|c|}
\hline \multirow{2}{*}{ No. } & \multirow{2}{*}{ Year } & \multirow{2}{*}{ Title of Training and Demonstration } & \multicolumn{3}{|c|}{ Participants } & \multirow{2}{*}{ Total } \\
\hline & & & Farmers & DA's & Administration & \\
\hline \multirow[t]{2}{*}{1} & \multirow{2}{*}{2011} & $\begin{array}{l}\text { SWC, Vetiver, Coffee production and management, Lime } \\
\text { technology }\end{array}$ & 30 & 5 & 10 & 45 \\
\hline & & Seedling and Plantation management & 10 & 11 & 10 & 31 \\
\hline \multirow[t]{2}{*}{2} & \multirow{2}{*}{2012} & $\begin{array}{c}\text { Banana, Potato, Coffee, and cereal production and manage- } \\
\text { ment }\end{array}$ & 89 & 11 & 10 & 110 \\
\hline & & Awramba Energy saving stove technology & 30 & 8 & 10 & 48 \\
\hline 3 & 2013 & $\begin{array}{l}\text { Banana, Potato, Coffee, and cereal production and manage- } \\
\text { ment. }\end{array}$ & 55 & 6 & 6 & 67 \\
\hline 4 & 2014 & $\begin{array}{l}\text { Construction of improved beehive from local available ma- } \\
\text { terial, and Tree plant seedling production and management }\end{array}$ & 50 & 6 & 3 & 59 \\
\hline Total & & & 264 & 47 & 49 & 360 \\
\hline
\end{tabular}

Source: [10-13].

Implementation and evaluation of biological and physical soil and water conservation measures

Soil erosion problem is one of the main prioritized problem of the watershed. Thus, to limit the soil loss due to severe soil erosion to acceptable level huge soil and water conservation structure was constructed to reduce run off velocity and enhancing infiltration of runoff into the soil. Soil bund of more than $190 \mathrm{~km} \mathrm{(85 \% )}$ of watershed or 320 hectare) has been constructed through 
community mobilization and some of the structures covered with biological means (vetiver grass, Susbania and other agroforestry tree seedlings). The Vetiver grasses were introduced and planted with $20 * 20 \mathrm{~cm}$ inter and intra row spacing with staggered pattern as hedgerows and integrated with a soil bund as a stabilizer. Most of the Vetiver hedgerows have been established successfully. More than $45 \mathrm{~km} \mathrm{(20 \% )}$ of watershed or 75 hectares has been covered by Vetiver hedgerows on soil bund and without soil bund [14]. The established level soil bund stabilized with Vetiver was significantly $(\mathrm{p}<0.01)$ affected soil moisture content $(\%)$, bulk density $\left(\mathrm{g} / \mathrm{cm}^{3}\right)$, and soil organic carbon (\%) as compared to un conserved cropland at Somodo Watershed [14].

The slope of the farm land treated with Vetiver hedgerows was reduced by $2.5 \%$ as compared to before the establishment of hedgerows on the farmlands [13]. This reveals that the effectiveness of the Vetiver hedgerows in reducing the velocity of the runoff and result in accumulation of sediment above the slope. That enhance development of the bench terrace through time and improve physicochemical properties of the soil. For instance, the average available phosphorous of above hedgerow of the farm lands was enhanced three times of below hedgerow lands that was from $1 \mathrm{ppm}$ to $4 \mathrm{ppm}$. While, exchangeable acidity of above hedgerow farm lands was minimized than below hedgerow lands from 0.9 to $0.5 \mathrm{Meq} / 100 \mathrm{~g}$ of soil. Similarly, the established Vetiver hedgerows was reduced slope of treated farmland as compared to untreated adjacent farmland at Haru district, western Ethiopia [15].

\section{Establishment of community nursery and plantation of niche compatible multipurpose tree species in model watershed}

Deforestation due expansion of agricultural land, logging, charcoal and fuel wood production are another identified problem that contribute to soil erosion and land degradation of the watershed. Accordingly, to improve the forest cover of the watershed, eight community nursery in 2011/2012 and two in 2013/2014 were established in a watershed with organizing user groups and introduce different highland variety of specialty coffees, coffee shade trees and multipurpose trees were raised within all sites (Table 2).

Table 2: Number of coffee shade and multipurpose tree seedlings.

\begin{tabular}{|c|c|c|c|c|c|}
\hline № & Species & Unit & $2011 / 2012$ & $2012 / 2013$ & Total \\
\hline 1 & Acacia Abyssinica & № & 4,000 & 675 & 4,675 \\
\hline 2 & Fedharbia Albida & № & 4,000 & 500 & 4,500 \\
\hline 3 & Gravillea Robusta & № & 4,000 & 1585 & 5,585 \\
\hline 4 & Cordia Africana & № & 3,000 & - & 3,000 \\
\hline 5 & Acacia Decurrence & № & 2,000 & 1500 & 3,500 \\
\hline 6 & Chamaecytisus Palmensis /Tree Lucerne/ & № & 3,000 & - & 3,000 \\
\hline 7 & Tid & № & - & 1195 & 1,195 \\
\hline $\begin{array}{l}\text { To- } \\
\text { tal }\end{array}$ & & № & 20,000 & 5,455 & 25,455 \\
\hline
\end{tabular}

Source: [12].

The establishments of the community nursery at their farm levels were enabled farmers to produce improved coffee variety and multipurpose forest tree seedlings sustainable. Furthermore, it creates the opportunity of income generation from selling of seedlings to non-producers.

Indigenous and exotic tree species such as Grevillea, Tid, Different acacia species, different coffee shade trees and coffee seedlings have been planted around the farms and homesteads fences. About $20 \%$ of household (60 Household farmers) were considered in the impact assessment survey. Then, more than 13,608 woody biomass fuels are available after the interventions. These tree species were raised at community nursery site, distributed and planted within community were increased the watershed forest cover and decreased deforestation [16].

\section{Introduction of different improved and high yielding crop varieties}

Low production due to use of local variety and reduced soil fertility was also the main problem of the watershed. In 2011, improved variety of grafted avocado seedlings were introduced to the watershed. Some of the seedlings were established successfully in model watershed. More than 40,000 seedlings of five highland coffee varieties have been raised in Somodo watershed nurseries in 2012. More than 5000 and 1000 coffee seedlings were distributed in 2013 and 2014, respectively. Also, more than 500 bananas (five variety), Teff (Qunco and kora varieties), Barley (BH-1370), Soybean Clarck 63K were distributed for farmers to introduce and evaluate for their adaptability and productivity. Potato (Gudane) variety was also well adapted in the watershed 
and mean of $18,956 \mathrm{~kg} \mathrm{ha}^{-1}$ of yield have been gained up to the maximum yield of $31,660 \mathrm{~kg} \mathrm{ha}^{-1}$ (Figure 1). These interventions were improved the productivity and production of the watershed.
High yield had been obtained due to row sowing over the broadcast within different crop types and varieties. The difference in yield also accounted in different location of the watershed due to edaphic heterogeneity and altitudinal variability (Table 3).

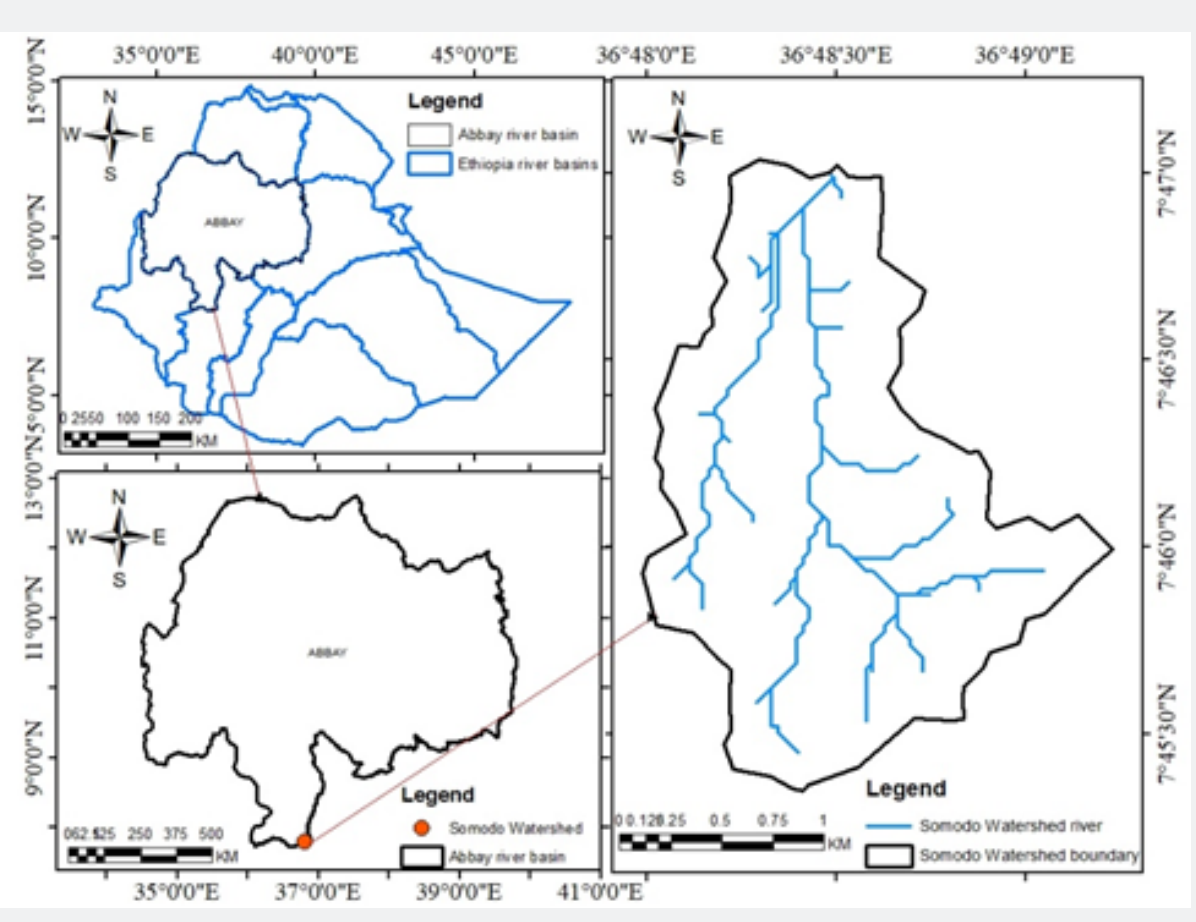

Figure 1: Map of Somodo Watershed, Jimma Zone, Southwestern Ethiopia.

Table 3: Yield of different crops as affected by location, sowing methods and variety.

\begin{tabular}{|c|c|c|c|c|}
\hline № & Crop Type & Variety & № of Location & Average Yield (kg ha-1) \\
\hline 1 & Teff (Row) & Qunco & 6 & 1854 \\
\hline 2 & Teff (Broadcast) & Qunco & 2 & 1600 \\
\hline 3 & Teff (Broadcast) & Yirga (local) & 2 & 900 \\
\hline 4 & Teff (Broadcast) & Qorotome (local) & 2 & 900 \\
\hline 5 & Teff (Broadcast) & Gomo (local) & 2 & 875 \\
\hline 6 & Lentl (Broadcast) & Alemayehu & 4 & 1000 \\
\hline 7 & Niger Seed (Row) & Ginchi & 4 & 875 \\
\hline & 8 & Ginchi & 4 & 1125 \\
\hline 10 & Niger Seed (Broadcast) & Kuyu & 4 & 875 \\
\hline 11 & Niger Seed (Row) & Kuyu & 4 & 1150 \\
\hline 12 & Niger Seed (Broadcast) & Shambu & 4 & 1000 \\
\hline 13 & Niger Seed (Row) & Shambu & 2 & 1125 \\
\hline
\end{tabular}




\section{International Journal of Environmental Sciences \& Natural Resources}

\begin{tabular}{|c|c|c|c|c|}
\hline 14 & Wheat (Row) & Dendeha & 7 & 3292 \\
\hline 15 & Wheat (Broadcast) & Dendeha & 7 & 2875 \\
\hline 16 & Wheat (Broadcast) & Qeqeba & 9 & 2800 \\
\hline 17 & Potato (row) & Gudane & 2 & 36956 \\
\hline 18 & Barley (row) & BH 1307 & 2 & 3000 \\
\hline 19 & Barley (Broadcast) & BH 1307 & 2 & 2063 \\
\hline 20 & Barley (row) & SIM 21 & 2 & 1617 \\
\hline 21 & Barley (Broadcast) & SIM 21 & 25 \\
\hline
\end{tabular}

Source: [12].

\section{Introduction and demonstration of lime technologies}

In Somodo watershed, introduction of lime technology started in 2011. Lime pre-scaling up trial was laid down to evaluate the effect of lime on the yield of maize and soil chemical properties. The intervention at each site involved two treatments (with and without lime) and the plot size was $10 * 10$ when started, and maize variety $\mathrm{BH} 660$ has been used as a test crop. However after introducing the technology the large scale demonstration $\left(2500 \mathrm{~m}^{2}\right)$ covered with lime for each 140 farmers (35ha). Where the recommended fertilizer to the area $\left(46 \mathrm{P}_{2} \mathrm{O}_{5}\right.$ or $100 \mathrm{~kg}$ of DAP, and $92 \mathrm{~N}$ or $200 \mathrm{~kg}$ of Urea ha ${ }^{-1}$ ) has been applied. On average, more than $866 \mathrm{~kg}$ maize yield was obtained from lime applied plots over un-limed that mean, $4286 \mathrm{~kg} \mathrm{ha}^{-1}$ and $3420 \mathrm{~kg} \mathrm{ha}^{-1}$ from with and without lime, respectively (Figure 2). Moreover, the soil $\mathrm{pH}$ has slightly increased for most of the locations. Soybean was used to evaluate residual lime effect at Somodo. The limed plot has given $275 \mathrm{~kg} \mathrm{ha}^{-1}$ yield difference when compared with yield obtained from without lime [12]. The farm land treated with lime increased maize yields by $866 \mathrm{~kg} \mathrm{ha}^{-1}$ advantage over un-limed. Whereas, the residual effects of lime provide $275 \mathrm{~kg} \mathrm{ha}^{-1}$ yield advantage over un-limed to Soybean crop. The $\mathrm{pH}$ of the soil was slightly improved under most of the locations that might enhance the availability of the nutrients (Figure 3 ).

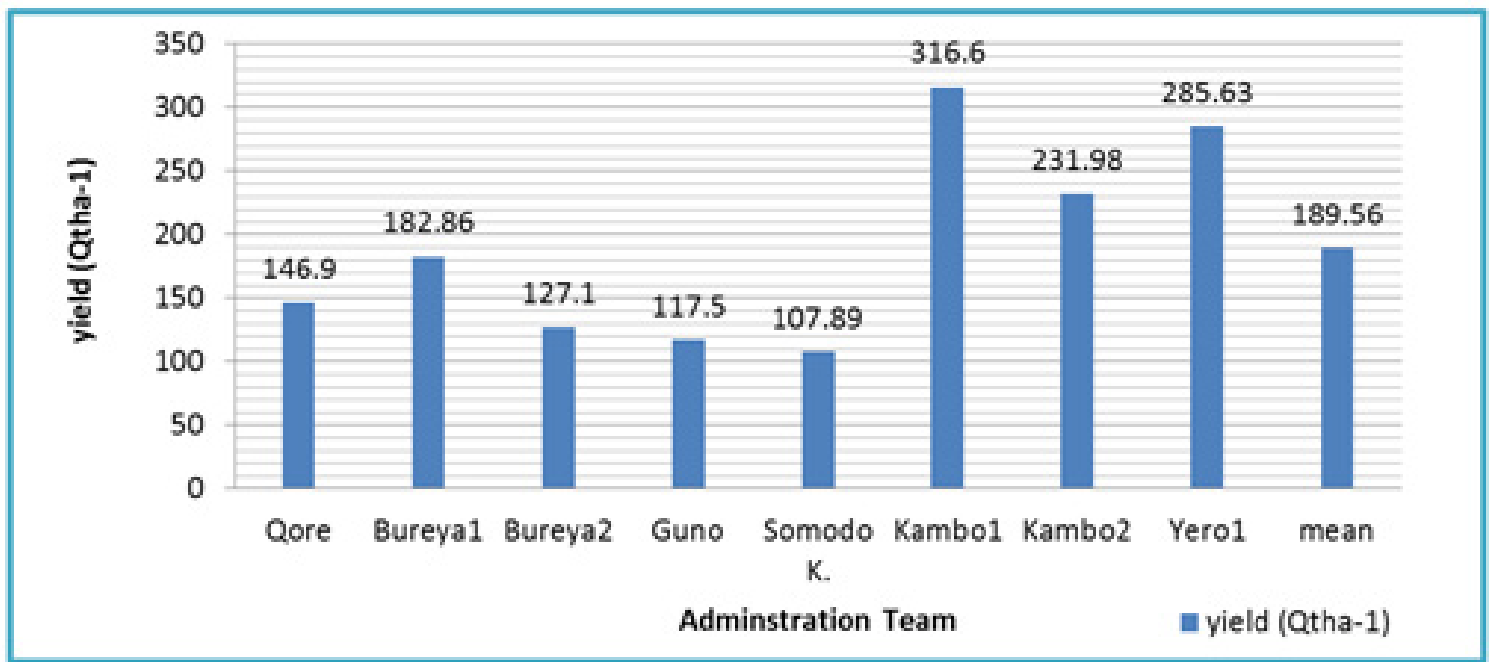

Figure 2: Evaluation of Gudane potato variety in Somodo model watershed.

Source: [12].

\section{Introduction and demonstration of improved energy saving stoves}

The energy consumption of the households of the watershed depends on forest resource and biomass [17]. Training on Awramba energy saving stove construction and use has been given on June 2012. During the training, Awramba energy saving stove has been constructed for one farmer in model watershed. In 2014, 12 women participated in training on how to construct and use the energy 
saving stove. After training, they cooperated to construct the stove and sell to farmers in the watershed and those living around the watershed and the cooperative had been earned 15000 ETB within 6 months [12].

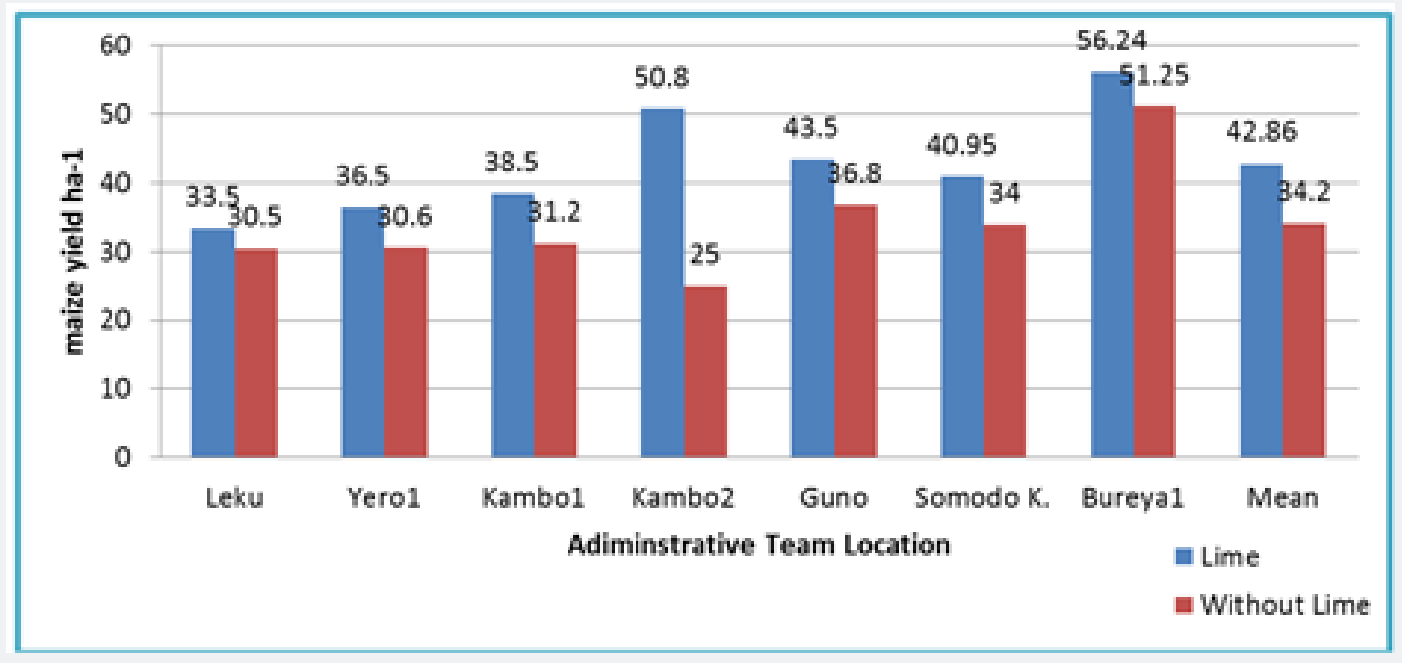

Figure 3: The effect of lime on yield of maize.

Source: [12].

\section{Demonstration and evaluation of conservation agriculture}

For Soybean crop, conventional tillage operation has shown high yield potential at all year except 2019 year over conservation or minimum tillage operation (Figure 4). These have needed further investigation to know the mechanism of crops favor conventional tillage.

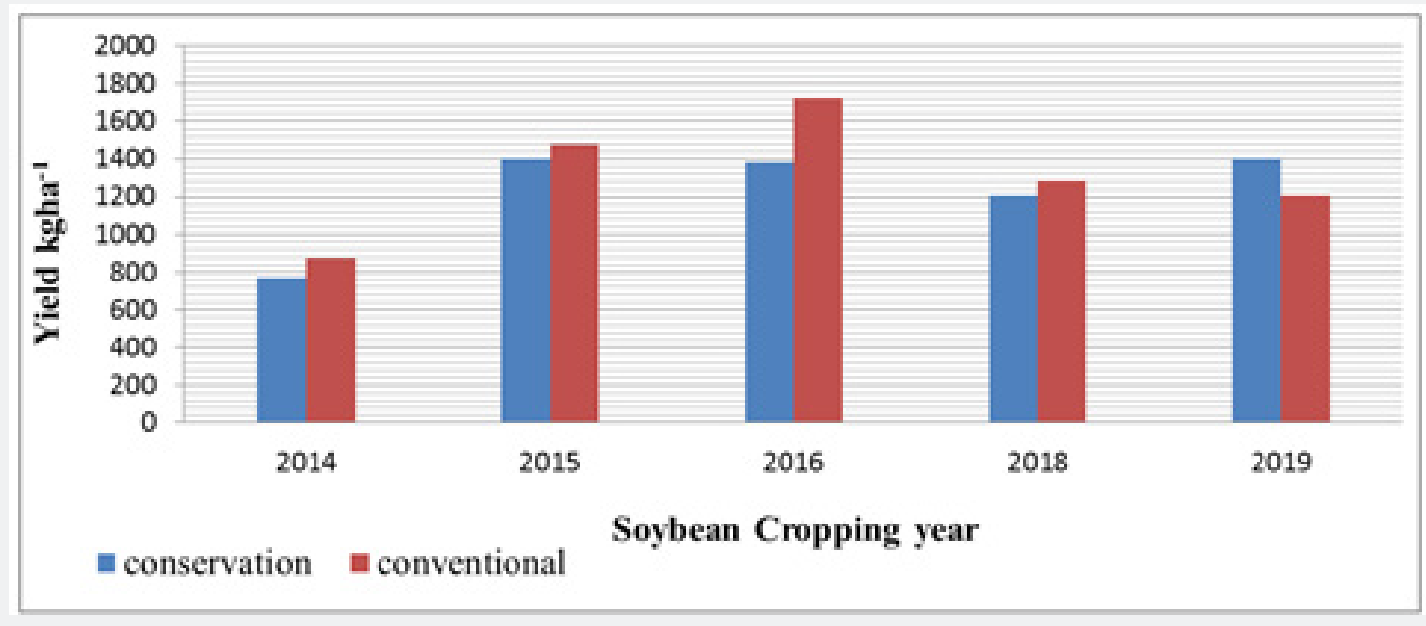

Figure 4: Conservation Agriculture to Soybean Crop.

Source: [17].

For Maize crop, Conservation tillage operation has shown high yield potential at all year over conventional tillage operation (Figure 5). These also have needed further investigation to know the mechanism of crops favor conservation tillage. This might be due to crop root system and Maize crop favored from crop rotation with soybean. 


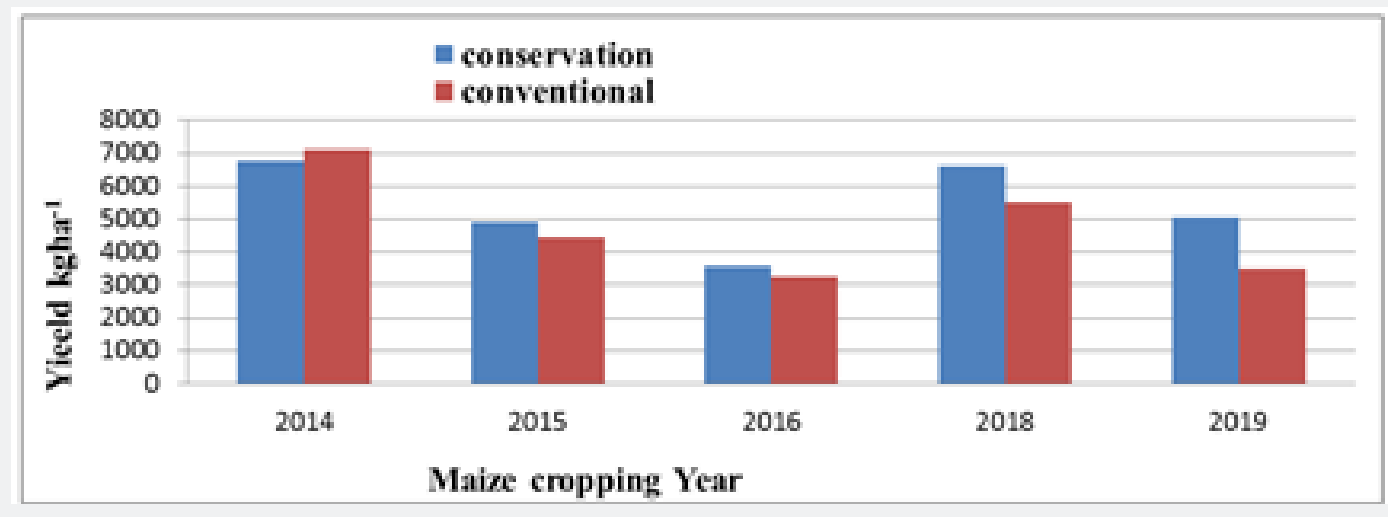

Figure 5: Conservation Agriculture to Maize Crop.

Source: [17].

Introduction and evaluation of livestock, poultry and apiculture technologies in the model watershed

Trainings were given to farmers on the importance of artificial insemination (AI) in improving the productivity of dairies. From each peasant association or Geres cows with good performance were selected and artificially inseminated. Fifteen cows were totally inseminated, and ten cows gave birth [12].

In 2012, 50 chickens a day old with three-month forage were given for each selected model farmers for free. Totally 15 one day old chickens were introduced into Somodo watershed in 2012. Their survival rate by that year was $70 \%$. Neighboring farmers were highly interested in the breeds and they bought these breed eggs from these model farmers. In 2014 another five model farmer was selected and constructed house for chickens and paid 6 ETB for each chicken then 300 ETB collected from individual farmers. About 300 one day old chickens were bought from Debrezeit Agricultural Research Center and distributed to selected model farmers with three-month balanced forage. The survival rate of these chickens was $65 \%$. These were helped to enhance the introduction and promotion of improved breeds of poultry and hence increase the productivity as well [12].

Transitional and modern beehives have been introduced in model watershed, Accordingly, more than 20 and 50 transitional and modern beehives, respectively were demonstrated in the watershed. Honey yield has been obtained $125 \mathrm{~kg}$ per one modern hive while $5 \mathrm{~kg}$ obtained from traditional hive [18].

\section{Introduction and evaluation of different forage crops/ feeds}

Awareness creation was given on the management and usage of locally available forage and fodder's. Rhodes and elephant grass were a major forage grasses which were introduced in model watershed and tree luceren as well sesbania sesban were introduced tree forages. Alfalfa, pigeon pea and oats were also introduced through inter-cropping between maize rows and used as animal feeds to enhance livestock production and productivity. Straws of crops also used as a feed source and aware the farmers on how to use it, training and awareness creation was given at over time.

\section{Characterization of different existing agroforestry practices and its effect on soil properties}

In Somodo watershed, Home garden Agroforestry, Plantation forest, farm forestry, Natural forest, cultivation land and grazing land are identified land uses. In home garden agro-forestry, coffee Arabica and Persia Americana species were the dominant one, but in plantation forestry, Grevillea Robusta and Coffee Arabica have a higher frequency. Concerning species richness, Albizia Gumifera, Coffee Arabica and Milletia Ferriginea were the dominant compared to other species found in natural agro-forestry in the area. However, in farm agro-forestry, Grevillea Robusta has a higher species richness in the watershed. Regarding importance value index (IVI), Coffee Arabica (103\%) and Albizia Gumifera $(47.77 \%)$ were higher importance value index in home garden agro-forestry. In plantation agro-forestry, coffee Arabica (61.3\%) and Croton Macrostachyus (59.5) have great IVI in the area. From natural agro-forestry, Coffee Arabica (108.2\%), in farm agroforestry Grevillea Robusta (104.99) and Croton Macrostachyus (48) have higher IVI value. IVI is an important parameter that reveals the ecological significance of species in a given ecosystem. Therefore, coffee Arabica, Albizia Gumifera, Grevillea Robusta and Croton Macrostachyus are widely adapted and economically important in the area [19].

\section{Impact Assessment in the Watershed}

After the interventions of integrated watershed management approach in model watershed; the livestock (5\%), other 
products $(3 \%)$ and business activities (2\%) has been increased in experimental group than in control group. However, the dependence on agriculture was reduced by $7 \%$ over the control group in the experimental group [5].
As described in (Table 4) physical and biological soil and water conservations, organic and inorganic fertilizer utilizations were exhibited higher mean value in the experimental group than the control group.

Table 4: Share of different income sources of households for experimental and control groups.

\begin{tabular}{|c|c|c|}
\hline Source of Incomes & Mean by Experimental Group & Mean by Control Group \\
\hline Soil Bund (km) & 38.5255 & 0 \\
\hline Fanyajuu (m) & 0.0606 & 1.3158 \\
\hline Drainage Dich (m) & 1.7626 & 3.75 \\
\hline Cut off drain (m) & 4.4975 & 20.5789 \\
\hline Fertilizer (kg) & 23.4271 & 24.2 \\
\hline Manure (qt) & 60 & 131.7763 \\
\hline Composite (qt) & 162.9293 & 30.5526 \\
\hline Mulching (Shekim) & 45.4545 & 9.3421 \\
\hline Vetiver hedge (km) & 39.7259 & 236.2417 \\
\hline Total land management & 366.383 & \\
\hline
\end{tabular}

Source [5].

In the watershed as compared to the base year, farmers' perception towards soil quality and soil erosion severity scale were improved as compared to interviewed farmers outside of the watershed. Apparently, this might be due to intervention of biological and physical soil and water conservation, awareness and utilization of organic and inorganic fertilizers widely in the watershed. Therefore, it is indispensable to scale up the technology to neighbor and others watershed with similar agro ecology.

Regarding usage of improved seeds, more farmers in the watershed were used an improved variety (82.5\%) than local varieties $(17.5 \%)$, while inversely farmers outside the watershed were used more local variety (42.4\%) and less improved variety (57.6\%). This clearly contributed for improved crop yields in the watershed as compared to farmers outside the watershed. The livestock holding for the experimental group is showed increment by 4.7 mean difference, while for control group 0.72 as compared to base year. Socioeconomic related factors of both farmers of the watershed and outside of the watershed were shown improvement as compared to base year. However, higher mean was recorded for the experimental group than control group as described in [5].

\section{Monitoring the Discharge and Sediment Yield at Somodo Watershed Outlet}

The long-term monitoring of water flow discharge and sediment losses from the catchment area of watershed have been measured twice a day and taken additionally at raining time. As the data summarized shown with trend analysis, generally the discharge of water flow recorded at the watershed outlet had showed increasing trends whereas sediment yield recorded shown the decreasing manner from the initial years of the project due to integrated watershed management interventions. However, the rainfall amount that had been recoded doesn't show the difference within duration of interventions while it has been oscillated. Flow discharge data taken within full years showed increasing trend by $11.46 \%$ whereas sediment loss become shown decreasing trend by $36.31 \%$, this is due to integrated watershed management especially physical and biological soil and water conservation-measures.

As the table blow shown, there is a negative correlation/ relationship between year of interventions and the amount of sediment loss. However, strong relationship between year of interventions and flow discharge was observed due to soil erosion decreased by increasing soil infiltration capacity that mean when integrated watershed management interventions continued for a year, the run-off volume enter watershed had decreased in the watershed and the river base flow volumes become increased while the sediment loss decreasing because those interventions contributes to reduce the run-off velocity and reduce surface runoff then gives a time to infiltration [21]. After infiltration, clean water generated as a spring and flows as a river constantly. For this reasons the clean base flow of watershed, increasing every year. The rainfall amount and discharge, rain fall amount and sediment loss, flow discharge and sediment loss record the positive relationship this effect for each other's (Table 5). 
Table 5: Correlation between parameters.

\begin{tabular}{|c|c|c|}
\hline Factors & Cor. & $\operatorname{Pr}(>|\mathbf{t}|)$ \\
\hline Year: Rain fall & -0.028 & 0.942 \\
\hline Year: Discharge & 0.753 & 0.01921 \\
\hline Year: SSY & -0.084 & 0.8309 \\
\hline Rainfall: Discharge & 0.393 & 0.2952 \\
\hline Rainfall: SSY & 0.242 & 0.5311 \\
\hline Discharge: SSY & 0.378 & 0.3164 \\
\hline
\end{tabular}

Source: [20].

\section{Conclusion}

The Somodo model watershed is characterized by different land use types by cultivation land domination and less forested area and receives high annual rainfall, these resulted to land degradation due to soil erosion. To hinder these problems, several integrated watershed management interventions have been selected as well as implemented with capacitating the farmer's indigenous knowledge. After that, the evaluation of interventions impact on socioeconomic and biophysical components of the watershed has been identified by using watershed impact assessment survey, field and laboratory soil plant analysis. The effective and promising results which observed from assessment, field observation and analysis of interventions are Soil erosion were reduced, the watershed base flow volume has been increased, the rate of soil acidification was retarded, soil fertility status was improved, livestock breeds and feeding system have improved, trend of traditional farming systems was transferred to improved and modern system, and yield potential of the watershed have increased. Generally, the watershed biophysical and socioeconomic has improved. Therefore, it is better to scale up the technology to the neighboring watershed and to similar agro-ecology across the country to manage our natural resource in sustainably, hence improve livelihood of the community.

\section{References}

1. Hurni H, Berhe WA, Chadhokar P, Daniel D, Gete Z, et al. (2016) Soil and water conservation in Ethiopia: guidelines for development agents.

2. Belayneh M, Abera A, Tadesse G (2017) Soil Degradation and Conservation Practices: the case of Darimu and Chewaka woredas, Illu Ababora Zone, Ethiopia. International Journal of Scientific and Research Publications 7(10): 562-568.

3. Pudasaini BP (2003) VDC Approach- A Key to Success in Participatory Watershed Management. A paper presented in the Regional Workshop on Watershed Management: A South Asian Perspective, 19- 21 November 2002, Kathmandu, Nepal.

4. Shiferaw B, Bantilan C, Wani S, Sreedevi TK, Nageswara Rao GD (2006) Collective Action for Integrated Community Watershed Management in Semi-Arid India: Analysis of Multiple Livelihood Impacts and the Drivers of Change. Contributed paper prepared for presentation at the International Association of Agricultural Economists Conference, Gold Coast, Australia, August 12-18, 2006.

5. Tesfaye G, Debebe Y, Yakob T (2018) Impact of Participatory Integrated Watershed Management on Hydrological, Environment of Watershed and Socio-Economic, Case Study at Somodo Watershed, South Western Ethiopia. The International Journal of Earth \& Environmental Sciences 3(1): 1-7.

6. Tesfaye G, Debebe Y, Fikirie K (2018) Soil Erosion Risk Assessment Using GIS Based USLE Model for Soil and Water Conservation Planning in Somodo Watershed, South West Ethiopia. Int J Environ Agric Res $4(5): 35-43$.

7. Alemayehu F, Tolera M, Tesfaye G (2019) Land Use Land Cover Change Trend and Its Drivers in Somodo Watershed South Western, Ethiopia. African Journal of Agricultural Research 14(2): 102-117.

8. Lakew D, Kassie M, Benin S, Pender J (2000) Land degradation and strategies for sustainable development in the Ethiopian highlands: Amhara Region. Socio-economics and Policy Research Working Paper 32, (Vol. 32). ILRI (aka ILCA and ILRAD).

9. Sileshi B, Holden ST (1998) Resource degradation and adoption of land conservation technologies in the Ethiopian Highlands: A case study in Andit Tid, North Shewa. Agricultural Economics 18(3): 233-247.

10. Jimma Agricultural Research Center (JARC) (2012) Research progress report for the period of 2011/2012. In: Shimbir T, Kebede T, Eshetu T, Atero B, Bezabih A (Eds.), EIAR/JARC, Jimma, p. 279 (232-238).

11. Jimma Agricultural Research Center (JARC) (2013) Research progress report for the period of 2012/2013. In Shimbir T, Kebede T, Eshetu T, Atero B, Bezabih A (Eds.), EIAR/JARC, Jimma, p. 251 (201-211).

12. Jimma Agricultural Research Center (JARC) (2014) Research progress report for the period of 2013/2014. In: Michael GW, Belete Y, Bekere W, Belachew K (Eds.), EIAR/JARC, Jimma, p. 261 (176-187).

13. Tesfaye G, Debebe Y, Yakob T (2018) Adoption and Effect of Vetiver Grass (Vetiveria zizanioides) on soil Erosion in Somodo Watershed, South-Western Ethiopia. OALib 05: 1-8.

14. Hailu L, Yimer F, Erkossa T (2020) Evaluation of the effectiveness of level soil bund and soil bund age on selected soil physicochemical properties in Somodo Watershed, Jimma Zone, SouthWestern Ethiopia. J Degrade Min Land Manage 8(1): 2491-2502.

15. Leta H, Gizaw T, Tesfaye Y (2020) Effect of Vetiver Grass (Vetiver Zizanodes) Hedgerows on Selected Soil Properties and Crop Yield on Farm Land at Haru District, Western Ethiopia. International Journal of Research Studies in Agricultural Sciences (IJRSAS) 6(5): 35-41.

16. Kalkidan F, Yalemtsehay D, Gizaw T (2017) Assessment of Woody and Non-Woody Fuel Biomass Resource Availability and Rate of Consumption in the Somodo Model Watershed South-Western Ethiopia. Journal of Environment and Earth Science 7(4).

17. Jimma Agricultural Research Center (JARC) (2016)Research progress report for the period of 2015/2016. In: Mikael GH, Belachew K, Tulu L, Mariam EG, Debebe Y (Eds.), EIAR/JARC, Jimma, p. 276 (181-184).

18. Jimma Agricultural Research Center (JARC) (2015) Research progress report for the period of 2014/2015. In: Michael GW, Belachew K, Tulu L, Ayano A, Bekere W (Eds.), EIAR/JARC, Jimma, p. 276 (34-37, 208).

19. Jimma Agricultural Research Center (JARC) (2017) Research progress report for the period of 2016/2017. In: Mikael GH, Belachew K, Mariam EG, Debebe Y (Eds.), EIAR/JARC, Jimma, p. 298 (46-50, 221-229).

20. Jimma Agricultural Research Center (JARC) (2018)Research progress report for the period of 2017/2018. In: Mikael GH, Seyoum H, Debebe Y, Tefera F, Kebede D (Eds.), EIAR/JARC, Jimma, p. 236 (36-38, 155165).

21. Dagnew DC, Guzman CD, Zegeye AD, Tibebu TY, Getaneh M, et al. (2015) Impact of conservation practices on runoff and soil loss in the sub-humid Ethiopian Highlands: The Debre Mawi watershed. J Hydrol Hydromech 63(3): 210-219. 
Your next submission with Juniper Publishers will reach you the below assets

- Quality Editorial service

- Swift Peer Review

- Reprints availability

- E-prints Service

- Manuscript Podcast for convenient understanding

- Global attainment for your research

- Manuscript accessibility in different formats ( Pdf, E-pub, Full Text, Audio)

- Unceasing customer service

Track the below URL for one-step submission https://juniperpublishers.com/online-submission.php 